УДК 553.985.1; 662.641.546.45; https://doi.org/10.37878/2708-0080/2021-4.06

\title{
ИЗУЧЕНИЕ КОМПОНЕНТНОГО СОСТАВА НЕФТЕБИТУМИНОЗНОЙ ПОРОДЫ МЕСТОРОЖДЕНИЯ КОЙКАРА
}

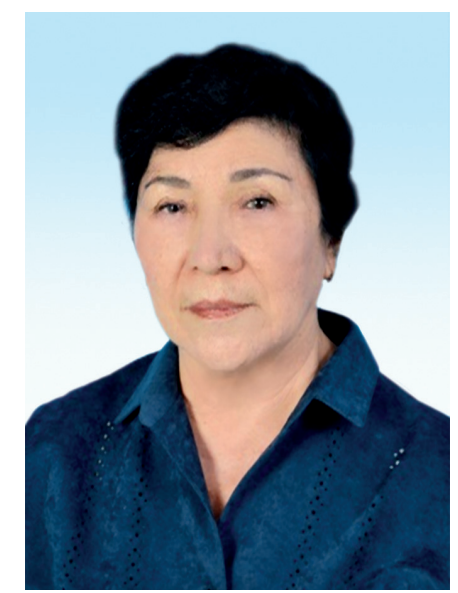

\footnotetext{
Н.К. ИШМУХАМЕДОВА ${ }^{1 *}$, доктор технических наук, главный научный сотрудник, https://orcid.org/ 0000-0001-87646979
}

${ }^{1}$ НАО «АТЫРАУСКИЙ УНИВЕРСИТЕТ НЕФТИ И ГАЗА ИМ. САФИ УТЕБАЕВА», Республика Казахстан, 060027, г. Атырау, ул. М. Баймуханова, 45-а

Целью данного исследования было выделение и изучение компонентного состава нефртебитуминозной породы месторождения Койкара, а также выявление закономерности изменения элементного и компонентного составов в зависимости от глубины залегания нефртебитуминозной породы и ректифрикация изучаемой нефттебитуминозной породы на установке АРН-2.

В отличие от Канады месторождения нефттебитуминозных пород Западного Казахстана разбросаны на значительной территории, например, только в Жылыойском районе Атырауской области недалеко от города Кульсары сосредоточено более 20 месторождений нефтебитуминозных пород. Нами была составлена карта, где представлены месторождения этих нефртебитуминозных пород.

Комплекс наших лабораторных исследований включает следующие этапы: 1) образцы нефтебитуминозной породы, периодически перемешивая, подвергают воздушной просушке под вытяжным шкафром, 2) после воздушной просушки, образцы нефтебитуминозной породы, периодически перемешивая, загружают в сушильный шкаф при температуре $50 \pm 5,3)$ после сушильного шкафра образцы нефртебитуминозной породы загружают в лабораторную шаровую мельницу и дробят, 4) затем образцы нефртебитуминозной породыупаковывают в тройной слой фильтровальной бумаги, перевязывают капроновой нитью и загружают в аппарат Сокслета.Извлечение природного битума из нефтебитуминозной породы проводят смесью элюентов: этиловый спирт (ректификат) и бензол в соотношении 1:3. Извлечение природного битума продолжают до тех пор, пока элюенты не станут прозрачными.

* Адрес для переписки. E-mail: nasima.ishmuhamedova@mail.ru 
После сушки регистрируют процентный выход природного битума. Затем элементный состав, молекулярную массу и компонентный состав природного битума определяют традиционными методами.

Из результатов полученных экспериментальных данных следует, что с уәлублением залегания породы меняется компонентный углеводородный состав природного битума, m.е. содержание масел уменьшается (с 8,3 до 7,0 \% масс.), а смол увеличивается (с 40,7 до 43,1 \% масс.), что отражается на снижении молекулярной массы (с 528 до 512 а.е.м.), а температура размягчения природного битума понижается (с 26 до $22^{\circ} \mathrm{C}$ ).

КЛЮЧЕВЫЕ СЛОВА: дорожное строительство, нефртебитуминозные породы, природные битумы, тяжелые нефти, месторождение Койкара, аппарат Сокслета, элементный состав, молекулярная масса, компонентный состав.

\section{ҚОЙҚАРА КЕН ОРНЫНЫҢ МҰНАЙ БИТУМИНОЗДЫ ЖЫНЫСТАРЫНЫН КОМПОНЕНТТІК ҚҰРАМЫН ЗЕРТТЕУ}

Н.К. ИШМУХАМЕДОВА ${ }^{1 *}$, техника ғылымдарының докторы, бас ғылыми қызметкер, https:// orcid.org/ 0000-0001-8764-6979

${ }^{1}$ «САФИ ӨТЕБАЕВ АТЫНДАҒЫ АТЫРАУ МҰНАЙ ЖӘНЕ ГАЗ УНИВЕРСИТЕТІ» КЕАҚ, Қазақстан Республикасы, 060027, Атырау қ, М. Баймұханов көшесі, 45-а

Бұл зерттеудің мақсаты Қойқара кен орнының мұнай битуминозды жынысының компоненттік құрамын анықтау және зерттеу, сондай-ақ мұнай битуминозды жынысының орналасу тереңдігіне байланысты элементтік және компоненттік құрамының өзгеру заңдылығын анықтау және АРН-2 қондырғысында зерттелетін мұнай битуминозды жыныстың ректификациялауы болды.

Канададан айырмашылығы Батыс Қазақстанның мұнай битуминозды жыныстарының кен орындары едәуір аумақта шашыраңқы орналасқан, мысалы, Атырау облысының Жылыой ауданында Құлсары қаласының маңында 20-дан астам мұнай битуминозды жыныстардың кен орындары шоғырланған. Біз осы мұнай битуминозды жыныстардың кен орындарын ұсынатын карта жасадық.

Біздің зертханалық зерттеулеріміздің кешені келесі кезеңдерді қамтиды: 1) мұнай битуминозды жыныстың үлгілері, мезгіл-мезгіл араластыра отырып, сорғыш шкафтың астына ауамен кептірілді; 2) ауамен кептіруден кейін мұнай битуминозды жыныстың үлгілері, мез-

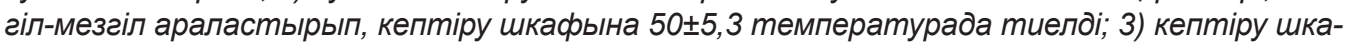
фынан кейін мұнай битуминозды жыныстың үлгілері зертханалық шар диірменіне тиеледі және ұсақталады; 4) содан кейін мұнай битуминозды жыныстың үлгілері сүзгі қағазының үш қабатына оралады., капрон жіппен байланған және Сокслет аппаратына жүктелген. Мұнай битуминозды жыныстан табиғи битумды алу элюенттердің қоспасымен жүзеге асырылады:этил спирті (ректифрикат) және бензол 1:3 қатынасында. Табиғи битумды алу элюенттер мөлдір болғанша жалғасады.

Кептіруден кейін табиғи битумның пайыздық шығымы тіркеледі. Содан кейін табиғи битумның элементтік құрамы, молекулалық массасы және компоненттік құрамы дәстүрлі әдістермен анықталады.

Алынған эксперименттік мәліметтердің нәтижелерінен жыныстың шоғыр тереңдеуімен табиғи битумның көмірсутек құрамы өзгереді, яғни май мөлшері азаяды (8,3-тен 7,0\% - ға дейін.), ал шайырлар көбейеді (40,7-ден 43,1\% - ға дейін.), яғни молекулалық массаның төмендеуіне әсер етеді (528-ден 512 а.е.м.), ал табиғи битумның жұмсарту температурасы төмендейді (26-дан $22^{\circ} \mathrm{C}$-қа дейін).

ТҮЙІн СӨзДЕР: жол құрылысы, мұнай битуминозды жыныстар, табиғи битумдар, ауыр мұнайлар, Қойқара кен орны, Сокслет аппараты, элементтік құрамы, молекулалық массасы, компоненттік құрамы. 


\title{
COMPOSITION OF OIL-BITUMINOUS ROCKS OF THE KOIKARA FIELD OF THE REPUBLIC OF KAZAKHSTAN
}

\author{
N.K. ISHMUHAMEDOVA ${ }^{1 *}$, Doctor of Technical Sciences, Chief Researcher, https://orcid.org/ \\ 0000-0001-8764-6979 \\ ${ }^{1}$ «ATYRAU OIL AND GAS UNIVERSITYNAMED AFTER SAFI UTERBAYEV» NJSC, \\ Republic of Kazakhstan, 060027, Atyrau, M. Baimukhanov st., 45-a
}

The purpose of this research was to isolate and study the component composition of the oilbituminous rock of the Koikara field as well as identifying the patterns of changes in the elemental and component compositions depending on the depth of the oil-bituminous rock and rectification of the studied oil-bituminous rock at the ARN-2 installation.

In contrast to Canada, the deposits of oil-bituminous rocks of Western Kazakhstan are scattered over a large area, for example, only in the Zhylyoy district of the Atyrau region, near the town of Kulsary, more than 20 deposits of oil-bituminous rocks are concentrated. We have compiled a map showing the deposits of these oil-bituminous rocks.

The complex of our laboratory tests includes the following stages: 1) samples of oil-bituminous rock, periodically stirring, were subjected to air drying under a fume hood, 2) after air drying, samples of oil-bituminous rock, periodically stirring, were loaded into a drying cabinet at a temperature of $50 \pm 5,3)$ after the drying cabinet, samples of oil-bituminous rock were loaded into a laboratory ball mill and crushed, 4) then samples of oil-bituminous rock were packed in a triple layer of filter paper, tied with nylon thread and loaded into a Soxhlet apparatus. Extraction of natural bitumen from oil- bituminous rock is carried out with a mixture of eluents: ethyl alcohol (rectified) and benzene in a ratio of 1:3. Extraction of natural bitumen is continued until the eluents become transparent.

After drying, the percentage yield of natural bitumen is recorded. Then the elemental composition, molecular weight and component composition of natural bitumen are determined by traditional methods.

From the results of the obtained experimental data, it follows that with the deepening of the rock, the component hydrocarbon composition of natural bitumen changes, i.e., the oil content decreases (from 8.3 to $7.0 \%$ by weight), and the resin content increases (from 40.7 to $43.1 \%$ by weight), which is reflected in a decrease in the molecular weight (from 528 to 512 a.u.m.), and the softening temperature of natural bitumen decreases (from 26 to $22^{\circ} \mathrm{C}$ ).

KEY WORDS: road construction, oil-bituminous rocks, natural bitumens, heavy oils, Koikara field, Soxhlet apparatus, elemental composition, molecular weight, component composition.

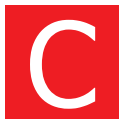

овременное дорожное строительство предъявляет высокие требования к дорожно-строительным материалам, особенно вяжущим, и в частности к битумам для асфальтобетона. В Республике Казахстан особенно актуально в связи с вводом в эксплуатацию новых автомобильных дорог по программе «Нұрлы жол» и требованиями по снижению затрат на ежегодный ремонт дорожного покрытия. В этой ситуации достаточно остро встают вопросы производства высококачественного дорожного битума, обеспечивающего значительное повышение долговечности битумно-бетонных покрытий - это во-первых, а во-вторых, необходимость резкого увеличения объемов дорожного строительства в республике обусловлена развитием транзитного потенциала страны, нарастанием грузоперевозок, осуществляемых автотранспортными средствами, расширением числа европейских и азиатских государств, участвующих в этом процессе. Интенсивность развития транзита в Казахстане и, как следствие, увеличение поступлений средств от него в государственный бюджет имеет прямую зависимость от технического состояния дорог и созданной инфраструктуры [1]. 
Для удовлетворения интенсивно развивающейся мировой топливно-энергетической и сырьевой промышленности требуется оперативное и широкомасштабное освоение альтернативных источников нефтехимического сырья. В этой связи все большую значимость приобретают нефтебитуминозные породы (НБП), природные битумы (ПБ) и близкие к ним по физико-химическим свойствам тяжелые нефти (TH) $[2,3]$.

По разным оценкам мировые запасы тяжелых нефтей и природных битумов составляют от 790 млрд т до 1 трлн т. Их роль значительно возрастает в связи с истощением месторождений нефти и природного газа и усложнением проблем их добычи. Месторождения природных битумов открыты на всех континентах земного шара, за исключением Австралии и Антарктиды. Наибольшими запасами природных битумов обладают Канада, Венесуэла и Россия. Значительное количество запасов сосредоточено также в США, Мексике, Кувейте, Индонезии. Запасы органической части битумсодержащих пород известных во всем мире месторождений составляют 300 - 330 млрд т, что практически эквивалентно всем потенциальным ресурсам нефти, и, в четыре раза превышают ее мировые доказанные запасы [4].

По оценкам экспертов, на территории Западного Казахстана запасы природных битумов составляют 1 млрд. тонн, а нефтебитуминозных пород - свыше 15-20 млрд т. Эти запасы находятся в Прикаспийской впадине и Северо-Западной части Туранской плиты в Западном Казахстане и залегают на глубинах до 120 м [5].

В работе [6] отмечено, что сосредоточение на территории Западного Казахстана месторождений нефтебитуминозных пород позволяет считать неоправданно забытым этот вид полезного ископаемого, при соответствующей обработке которого могут быть получены дорожный битум, топливо, строительные материалы. Опыт использования НБП в Казахстане имеется: в 1980-1990-х гг. прошлого столетия разрабатывалась государственная программа «Киры», была построена автомобильная дорога Макат-Актау. К настоящему времени большая часть потребности страны в дорожном битуме покрывается за счет импорта. Это значительный расход валютных средств, исчисляемых сотнями миллионов долларов.

Как отметил автор [7], в Казахстане имеется опыт использования строительных промышленных отходов по ранним разработкам. В 1981 - 1990 гг. Министерством автомобильных дорог Казахской ССР (министр Бекбулатов Ш.Х.) ежегодно осуществлялось строительство от 650 до 1600 км дорог с использованием отходов промышленности. Так, в течение 1981-1985 гг. было построено 3269 км и использовано 4 млн 720 тыс. т промышленных отходов, а в 1986-1987 гг. построено 3274 км и использовано 7 млн 503 тыс. т промышленных отходов. Применение нефтесодержащих пород позволило сэкономить дорогостоящий битум при строительстве 7000 км автомобильных дорог. В среднем экономия энергозатрат, по сравнению с традиционной технологией, составила 50-70 \%, трудозатрат - 20-40\%, экономический эффект - 40-60\%.

Из нефтебитуминозных пород Казахстана изучены природные битумы месторождений Западного Казахстана, таких как: Акший, Карасай, Копа, Мортук, Донгелексор, Кольжан, Тюбкараган [8]; Мунайлы-Мола, Иман- Кара [9-11]; Мортук [12];Тюбкараган [13], Канжига [14], Сатыпалды [15] и Алимбай [16]. 


\section{НЕФТЕХИМИЯ}

Значительный вклад в исследования природных битумов Западного Казахстана внесли: Н.К. Надиров, М.С.Трохименко, Г.А. Мусаев, В.Ф. Камьянов, А.Е. Браун, В.Г. Гуцалюк, Д.А. Розенталь, С.Х. Айгистова, А.Д. Кругинина, А.Г. Соколова, В.Я. Стрельникова, Ш.Х. Бекбулатов и др.

По данным IEA, AlbertaTRA, S. Holdich/OFSMarketing мировые нефтяные peсурсы оцениваются в 9-13 трлн баррелей, из них 30\% - легкие нефти, 40\% - тяжелые и сверхтяжелые (высоковязкие) и $30 \%$ - природные битумы [17]. В целом из динамики доказанных запасов нефти видно, что страны - лидеры нефтедобычи такие как Венесуэла, Канада, США восполняют свою ресурсную базу за счет трудно извлекаемых запасов углеводородов - высоковязких нефтей и природных битумов. Природные битумы являются основной долей профильных активов Канады, что определяет богатый опыт страны как в оценке и постановке на баланс нетрадиционных источников углеводородов, так и в технике и технологиях разработки. Передовой опыт Канады показывает, что, несмотря на увеличение капитальных вложений и эксплуатационных затрат, а также тарифов на транспортировку и ужесточение требований к охране окружающей среды, глобальный рост потребности в энергетических ресурсах, высокие цены на нефть и инновационные технологии позволяют рентабельно разрабатывать месторождения битумов и кратно увеличить их добычу. К примеру, если в 2010 г. добыча битумов составляла примерно 140 млн т, то к 2025 г. планируется увеличить ее до 240 млн т [18].

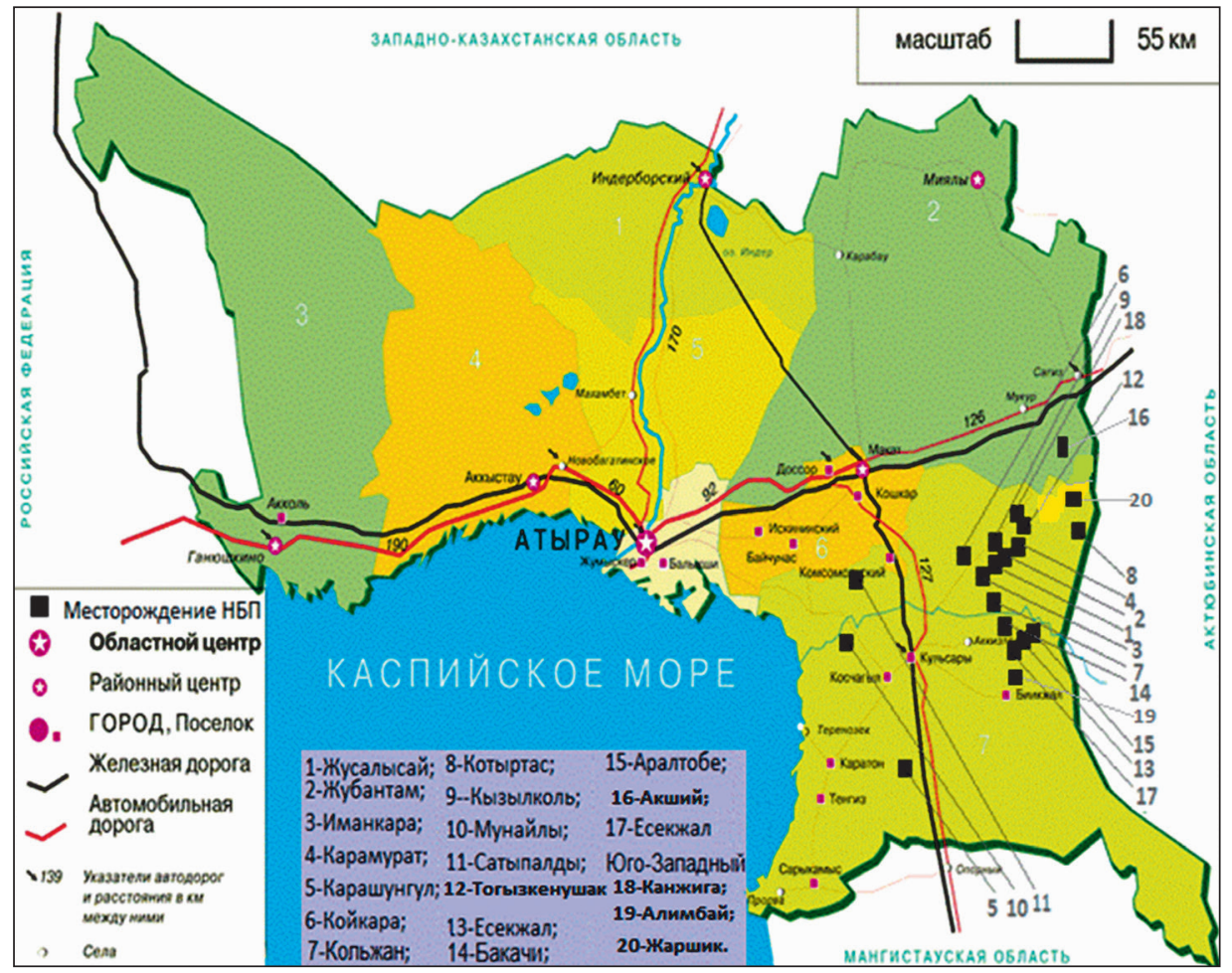

Рисунок 1 - Карта месторождений НБП Жылыойского района Атырауской области 
В отличие от Канады месторождения нефтебитуминозных пород Западного Казахстана разбросаны на значительной территории, например, только в Жылыойском районе Атырауской области недалеко от города Кульсары сосредоточено более 20 месторождений нефтебитуминозных пород.

Целью данного исследования было выделение и изучение компонентного состава нефтебитуминозной породы месторождений Койкара, выявление закономерности изменения элементного и компонентного составов в зависимости от глубины залегания нефтяного природного битума, а также выделение фракционного состава изучаемого НБП на установке АРН - 2.

Месторождение Койкара. Проявление нефтебитуминозных пород Койкара находится в пределах Жылыойского района Атырауской области, в 10 - 12 км к северо-западу от купола Иманкара. В тектоническом отношении проявление приурочено к одноименному соляному куполу. Тектоническая карта надсолевых комплексов представлена на рисунке 2.

В 1957 г. Койкаринское проявление битуминозных пород было обследовано М.Н. Кисилевой. По ее наблюдениям, выходы битумонасыщенных песчаников прослеживаются вдоль меридионального сброса северо-западнее от горы Койкара. Наиболее значительный из поверхностных выходов протягивается на 1000 м при средней ширине около 80 м и видимой мощности продуктивного тела 1,8 м. Для изученного участка была составлена геолого-литологическая карта и отобрана проба для аналитических исследований.

Содержание битума в породе составило $18 \%$. Ориентировочные запасы полезного ископаемого 350 тыс. т.

Поисковые работы на нефтебитумное сырье 1978 г. из-за ошибок в привязке и неиспользовании материалов картировочного бурения 1946 г. проведены за пределами выявленного ранее участка выходов нефтебитуминозных пород. Поэтому вывод о бесперспективности купола Койкара преждевременен и неправилен. Проявление не изучено детальными поисковыми работами [19].

Комплекс лабораторных исследований включал следующие этапы: воздушная подсушка под вытяжным шкафом.

1. Сушка в сушильном шкафу при температуре $50 \pm 5^{\circ} \mathrm{C}$.

2. Дробление проб нефтебитуминозной породы с помощью лабораторной шаровой мельницы.

3. Извлечение природного битума из НБП растворителями в аппарате Сокслета смесью: этиловый спирт (ректификат), бензол в соотношении 1:3.

4. Фракционный состав НБП выделили на установке АРН-2.

Элементный состав, молекулярную массу и компонентный состав определяли традиционными методами.

В таблице 1 даны характеристики усредненных проб природного битума месторождения Койкара, существенно различающиеся в зависимости от глубины отбора пробы по выходу битума и значениями кислотного числа, указывающего на наличие кислородсодержащих соединений. Аналогичные различия наблюдаются и при рассмотрении элементного и компонентного углеводородного составов. 


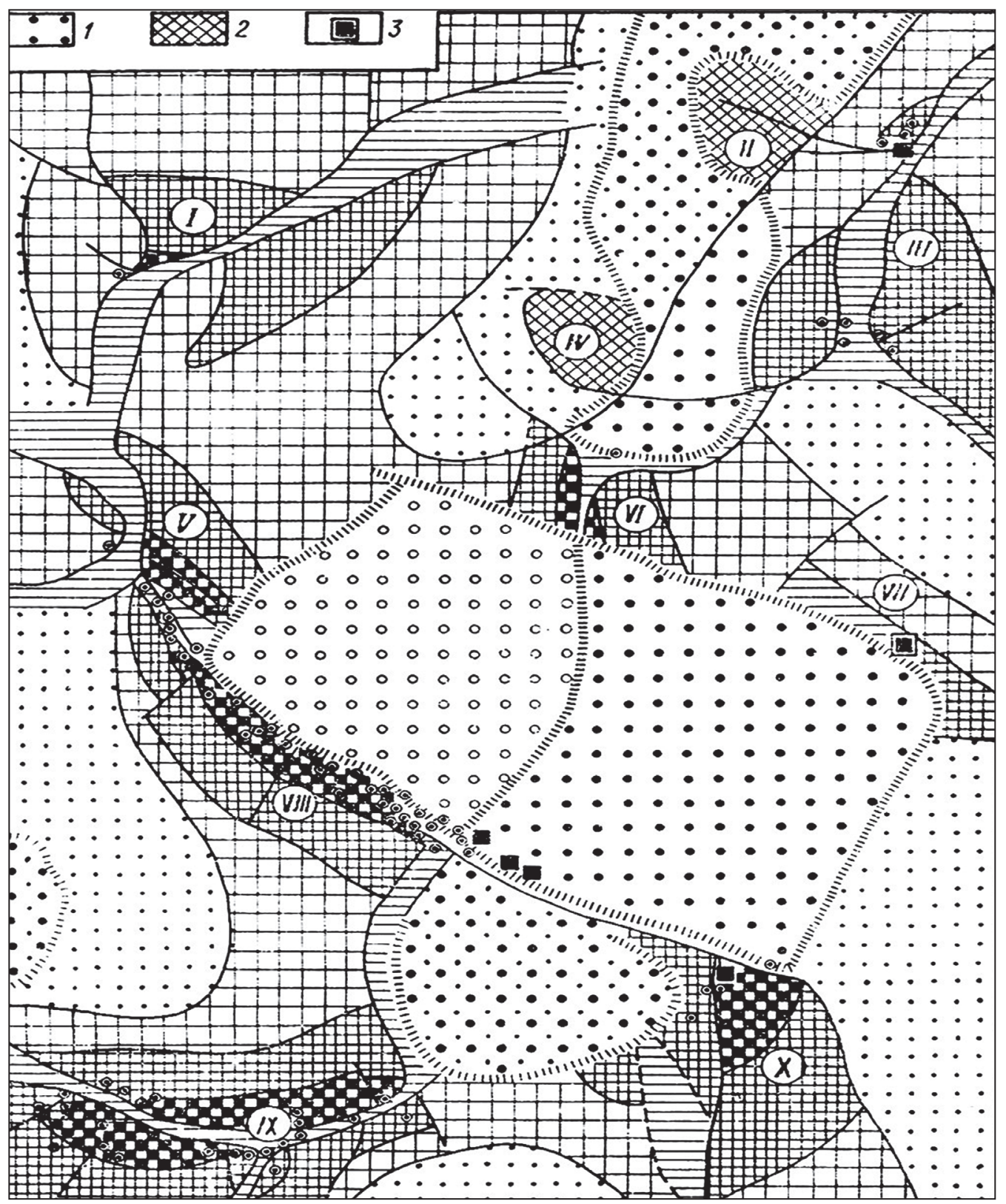

Рисунок 2 - Тектоническая карта надсолевых комплексов Алимбай, Акший, Койкара, Котыртас: 1 - дизъюнктивные палеомульды, компенсированные осадконакоплением; 2 - глубокопогруженные соляно-купольные структуры; 3 - месторождения нефтебитуминозных пород. Соляные купола: I - Молдабек Северный; II - Мурзалы Восточный; III - Акший Северный; IV - Котыртас Северный; V - Молдабек Южный; VI - Котыртас; VII - Акший; VIII - Алимбай; IX Камысколь Северный; X - Койкара 


\section{НЕФТЕХИМИЯ}

Из данных таблищь 1 следует, что с углублением залегания породы меняется компонентный углеводородный состав природного битума, т.е. содержание масел уменьшается (8,3-7,0\% масс.), а смол увеличивается (40,7-43,1\% масс.), что отражается на снижении молекулярной массы (с 528 до 512 а.е.м.), а температура размягчения природного битума понижается с 26 до $22^{\circ} \mathrm{C}$.

Полученные результаты показывают, что даже в пределах небольшой толщи породы происходят процессы миграции органического вещества по аналогии с

\begin{tabular}{|c|c|c|}
\hline Показания & \multicolumn{2}{|c|}{$\begin{array}{c}\text { Пробы из скважины № } 23 \\
\text { в зависимости от глубины залегания }\end{array}$} \\
\hline Глубина залегания, м & $3,0-8,5$ & $8,5-15$ \\
\hline $\begin{array}{c}\text { Кислотное число, мг КОН/г } \\
\text { битума }\end{array}$ & 15,17 & 13,95 \\
\hline $\begin{array}{l}\text { Выход природного битума, } \\
\text { среднее значение, \% масс. }\end{array}$ & 4,7 & 5,8 \\
\hline Молекулярная масса, а.е.м. & 528 & 512 \\
\hline $\begin{array}{c}\text { Температура размягчения по } \\
\text { КиШ, }{ }^{\circ} \mathrm{C}\end{array}$ & 26 & 22 \\
\hline $\begin{array}{c}\text { Содержание, \% масс.: } \\
\text { Асфальтенов }\end{array}$ & 16,8 & 18,6 \\
\hline Смол & 40,7 & 43,1 \\
\hline Парафина & 8,3 & 7,0 \\
\hline $\begin{array}{c}\text { Элементный состав, \% масс.: } \\
\text { С }\end{array}$ & 82,93 & 83,75 \\
\hline $\mathrm{H}$ & 8,89 & 8,43 \\
\hline$S$ & 1,57 & 1,52 \\
\hline$N+O^{x}$ & 5,85 & 5,97 \\
\hline $\begin{array}{c}\text { Выход фракций, \% масс. } \\
\text { НК }-200^{\circ} \mathrm{C}\end{array}$ & - & - \\
\hline $200-250^{\circ} \mathrm{C}$ & 2,36 & 3,14 \\
\hline $250-300^{\circ} \mathrm{C}$ & 3,82 & 4,27 \\
\hline $300-350^{\circ} \mathrm{C}$ & 4,53 & 5,83 \\
\hline $350-400^{\circ} \mathrm{C}$ & 7,68 & 9,32 \\
\hline $400-450^{\circ} \mathrm{C}$ & - & - \\
\hline $\mathrm{KK}-450^{\circ} \mathrm{C}$ & 11,7 & 13,5 \\
\hline
\end{tabular}

Таблица1 - Изменение свойств природного битума нестебитуминозной породы месторождения Койкара на примере скважины № 23 в зависимости от глубины залегания 


\section{НЕФТЕХИМИЯ}

процессами вторичной миграции нефти, сопровождающиеся природным хроматографическим эффектом, когда высокомолекулярные соединения удерживаются на поверхности минеральных зерен в отличие от более легких, неполярных соединений, которые беспрепятственно проходят во время движения органического вещества через породы.

По исследуемым образцам НБП скважины № 23 наблюдается снижение температуры размягчения природного битума с увеличением глубины залегания породы. Более высокая температура размягчения и более твердая консистенция органической составляющей верхних слоев породы объясняется длительным и интенсивным воздействием внешних факторов (солнечная радиация, кислород воздуха и т.д.).

Таким образом, установлено, что с углублением залегания породы меняется компонентный углеводородный состав природного битума, то есть содержание масел уменьшается, смол увеличивается, что отражается на снижении молекулярной массы и температуры размягчения битума.

Из результатов фракционирования НБП следует, что в глубинах залегания 3,0 - 8,5 м и 8,5 - 15 м низкокипящая фракция отсутствует и при разгонке $200-400^{\circ} \mathrm{C}$ выход фракции колеблется в пределах 2,36 - 7,68 и 3,14 - 9,32\% м.а.е. и при КК $450^{\circ} \mathrm{C}$ выход фракции составляет всего 11,7 и $13,2 \%$.

Химический состав минеральной части скважины № 23 представлен в таблице 2 в следующем соотношении \% масс: оксид кремния - 82,13, оксид железа - 2,88, оксид кальция - 1,72, оксид магния - 0,14 и оксид серы - 0,12.

Таблица 2 - Химический состав минеральной части нефтебитуминозной породы месторождения Койкара

\begin{tabular}{|c|c|c|c|c|c|c|}
\hline $\begin{array}{c}\text { Минеральная } \\
\text { часть, оксиды }\end{array}$ & $\mathrm{SiO}_{2}$ & $\mathrm{Fe}_{2} \mathrm{O}_{3}$ & $\mathrm{CaO}$ & $\mathrm{A}_{2} \mathrm{O}_{3}$ & $\mathrm{MgO}$ & $\mathbf{S O}_{3}$ \\
\hline Соотношение \% масс. & 82,13 & 2,87 & 1,72 & 0,60 & 0,14 & 0,12 \\
\hline
\end{tabular}

Минеральная часть НБП скважины № 23 представлена из суммы двух глубин породы: 3-8,5 + 8,5-15 м.

Таким образом, в результате пробных лабораторных исследований установлено, что с углублением залегания породы меняется компонентный углеводородный состав природного битума, т.е. содержание масел уменьшается, а смол увеличивается, что приводит к снижению молекулярной массы, температуры размягчения и кислотного числа битума.

Касательно фракционного состава изучаемого месторождения пока трудно оценить перспективность переработки НБП на углеводородное сырье. Из результатов выхода углеводородных фракций следует, что НБП месторождения Койкара могут найти применение в качестве одного из основных компонентов, применяемых при производстве материалов дорожного и строительного назначения. 


\section{ЛИТЕРАТУРА}

1 Preparation of modi fied oil road bitumen //E3S Web of Conferences, 2020, 175 (11030).15. Karimov O.K., Shakulikova G.T.,Ishmukhamedova N.K., Karimov E.

2 Надиров Н.К., Барак А., Трохименко М.С. Мортук - месторождение нефтебитуминозных пород, природных битумов и тяжелых нефтей как единый объект для комплексного освоения // Нефть и газ. - 2017. - № 6. - С. 22-41. [Nadirov N.K., Barak A., Trohimenko M.S. Mortuk - mestorozhdenie neftebituminoznyh porod, prirodnyh bitumov i tyazhelyh neftej kak edinyj ob"ekt dlya kompleksnogo osvoeniya // Neft' i gaz. - 2017. - № 6. - S. 22-41.]

3 Nadirov N.K., Barak A., Trokhimenko M.S. Disruptive technologies unlock potentials for efficient development of unique oil and bitumen field Mortuk // Нефрть и газ. - 2018. - № 5. - C. 47-64.

4 Муслимов Р.Х., Романов Г.П., Каюкова и др. Комплексное освоение тяжелых нефтей и природных битумов пермской системы Республики Татарстан. - Казань: Фэн, 2012. - 396 c. [Muslimov R.H., Romanov G.P., Kayukova i dr. Kompleksnoe osvoenie tyazhelyh neftej i prirodnyh bitumov permskoj sistemy Respubliki Tatarstan. - Kazan': Fen, 2012. - 396 s.]

5 Надиров Н.К., Трохименко М.С., Шестоперова Л.В., Жумалиева К.К. Тяжелые нефти - нетрадиционное углеводородное сырье (изученность, ресурсы, проблемы, перспективы) // Нефрть и газ. - 2018. - № 1. - C. 16-41. [Nadirov N.K., Trohimenko M.S., Shestoperova L.V., Zhumalieva K.K. Tyazhelye nefti - netradicionnoe uglevodorodnoe syr'e (izuchennost', resursy, problemy, perspektivy) // Neft' igaz. - 2018. - № 1. - S. 1641.]

6 Егоров О.И. Развитие нефтеперерабатывающих и нефтехимических секторов для эфффективного функционирования национальной экономики Республики Казахстан // Нефть и газ Казахстана. - 2020. - № 5(119). - C.96-103. [Egorov O.I. Razvitie neftepererabatyvashchih i neftekhimicheskih sektorov dlya effektivnogo funkcionirovaniya nacional'noj ekonomiki Respubliki Kazahstan // Neft' i gaz Kazahstana. - 2020. - № 5(119). - S. 96-103.]

7 Асматулаев Б.А. Нефтебитумсодержащие и промышленные техногенные материалы для строительства долговечных автомобильных дорог // Нефть и газ. - 2020. - № 5. - C.121-133. [Asmatulaev B.A. Neftebitumsoderzhashchie i promyshlennye tekhnogennye materialy dlya stroitel'stva dolgovechnyh avtomobil'nyh dorog // Neft' i gaz. - 2020. - № 5. - S. 121-133.]

8 Надиров Н. К., Мусаев Г. А., Ромашов Г. В. Исследование состава и свойств нефртебитуминозных пород Казахстана // Нефртехимия. - 1991. - Т. 31. - № 6. - С. 781-785.[Nadirov N. K., Musaev G. A., Romashov G. V. Issledovanie sostava i svojstv neftebituminoznyh porod Kazahstana // Neftekhimiya. - 1991. - T. 31. - № 6. - S. 781-785.]

9 Розенталь Д. А., Березников А. В., Федосова В. А. Изучение химического состава органической части киров с применением метода интегрального структурного анализа. Нефтебитуминозные породы. - Алма-Ата: Наука, 1982. - С. 94 - 98. [Rozental' D. A., Bereznikov A. V., Fedosova V. A. Izuchenie himicheskogo sostava organicheskoj chaste kirov s primeneniem metoda integral'nogo strukturnogo analiza. Neftebituminoznye porody. - Alma - Ata: Nauka, 1982. - S. 94 - 98.]

10 Гуцалюк В.Г., Сдобнов Е.И., Байтуова А.Д., Надиров Н.К., Рафиков С.Р. Исследование органической части месторождений Мунайлы-Мола и Иман-Кара. Нефртебитуминозные породы. - Алма-Ата: Наука, 1982. - С. 101-106. [Gucalyuk V.G., Sdobnov E.I., Bajtuova A.D., Nadirov N.K., Rafikov S.R. Issledovanie organicheskoj 


\section{НЕФТЕХИМИЯ}

chaste mestorozhdenij Munajly-Molailman-Kara. Neftebituminoznye porody. - Alma-Ata: Nauka, 1982. - S. 101-106.]

11 Айгистова С.Х., Садыков А.Н., Харламов В.А., Нигматуллина Р.Ш. Свойства органической части битуминозной породы киров месторождения Мунайлы-Мола. Нефтебитуминозные породы. - Алма-Ата: Наука, 1982. - С. 106-109. [Aigistova S.H., Sadykov A.N., Harlamov V.A., Nigmatullina R.SH. Svoistva organicheskoi chaste bituminoznoi porody kirov mestorozhdeniya Munajly-Mola. Neftebituminoznye porody. - Alma-Ata: Nauka, 1982. - S. 106-109.]

12 Камьянов В. Ф., Браун А. Е., Горбунова Л. В., Шаботкин И. Г. Природные битумы Мортука // Нефтехимия. - 1995. - Т. 35. - № 5. - С. 397- 409.

13 Соколова А.Г., Мусаев Г.А., Горенштейн Р.Г., Дюсенгалиев К.И. Парамагнитные свойства природных битумов и нефтей Западного Казахстана // Горючие сланцы. - 1993. - T. 10. - № 3-3. - C. 147-157.[Sokolova A.G., Musaev G.A., Gorenshtein R.G., Dyusengaliev K.I. Paramagnitnye svoistva prirodnyh bitumov i neftei Zapadnogo Kazahstana // Goryuchie slancy. - 1993. - T. 10. - № 3-3. - S. 147-157.]

14 Ishmukhamedova N. K. Road bitumens with the modifield additives // Science and technology. 2011, V. 6, P. 76-78.

15 Ишмухамедова Н. К. Изучение органической фракции нефтебитуминозной породы месторождения Сатыпалды // Нефттепереработка и нефтехимия. - 2016. - № 11. - С. 22-24. [Ishmuhamedova N. K. Izuchenie organicheskoj frakcii neftebituminoznoi porody mestorozhdeniya Satypaldy // Neftepererabotka i neftekhimiya. - 2016. - № 11. - S. 2224.]

16 Ишмухамедова Н. К., Каримов О.Х. Состав нефтебитуминозных пород месторождения Алимбай Республики Казахстан // Нефтегазовое дело. - 2017. - № 5. - C. 6 - 19.[Ishmuhamedova N. K., Karimov O.H. Sostav neftebituminoznyh porod mestorozhdeniya Alimbai Respubliki Kazahstan // Neftegazovoe delo. - 2017. - № 5. S. 6 - 19.]

17 Heavyoilinfo.com, Schlumberger (Электронный ресурс). Режим доступа: http://www. heavyoilinfo.com/

18 Nation Energy Board. Natural Resources Canada. The Oil Sands: Challenges and Opportunities (Электронный ресурс). Режим доступа: http://www.neb-one.gc.ca/clfnsi/rcmmn/bm-eng.html/.

19 Надиров Н.К. Высоковязкие нефти и природные битумы. - Т. 5. - Алматы: «Ғылым»,2001. - 336 с.[Nadirov N.K. Vysokovyazkie nefti i prirodnye bitumy. - T. 5. Almaty: «Fylym», 2001. - 336 s.] 